\title{
Gastrointestinal parasites of sheep, municipality of Lajes, Rio Grande do Norte, Brazil
}

\author{
Parasitos do trato gastrintestinal de ovinos, município de Lajes, Rio Grande do Norte, Brasil \\ Maria de Fátima de Souza ${ }^{1 *}$; Manoel Pimentel-Neto ${ }^{1}$; Rízia Maria da Silva ${ }^{1}$; \\ Albeísa Cleyse Batista Farias ${ }^{1}$; Marcos Pezzi Guimarães ${ }^{2}$
}

\begin{abstract}
${ }^{1}$ Departamento de Microbiologia e Parasitologia - DMP, Centro de Biociências - CB, Universidade Federal do Rio Grande do Norte - UFRN

${ }^{2}$ Programa de Pós-Graduação em Parasitologia, Instituto de Ciências Biológicas - ICB, Universidade Federal de Minas Gerais - UFMG
\end{abstract}

Received April 15, 2011

Accepted May 26, 2011

\begin{abstract}
This study investigated the gastrointestinal parasitism by helminths and protozoa in sheep (Ovis aries) Santa Inês breed, municipality of Lajes, Rio Grande do Norte. Monthly, from April 2005 to August 2007, stool samples were collected from two tracer lambs in the first day of the experiment and performed a necropsy of these animals in $44^{\text {th }}$ day. A total of 64 lambs were sampled, but only 62 lambs were slaughtered. The fecal samples were examined by sedimentation in water. The contents of the abomasum, small intestine and large intestine were examined for the recovery of helminths. The parasitological examination revealed eggs of the following groups of helminths: Strongyloidea, Strongyloides sp., Trichuris sp., and Moniezia sp. Also were found oocysts of Eimeria spp., cysts of Entamoeba ovis and Giardia duodenalis. The helminths identified from examining the contents were: Haemonchus contortus, Cooperia pectinata, Cooperia punctata, Trichostrongylus colubriformis, Moniezia expansa, Oesophagostomum sp. Skrjabinema ovis and Trichuris sp.
\end{abstract}

Keywords: Sheep production, Haemonchus contortus, Trichostrongylus spp., Giardia duodenalis, tracer lambs.

\section{Resumo}

O presente estudo investigou o parasitismo gastrintestinal por helmintos e protozoários em ovinos (Ovis aries) da raça Santa Inês, no município de Lajes, Rio Grande do Norte. Mensalmente, entre abril de 2005 e agosto de 2007, foram coletadas amostras fecais de dois cordeiros traçadores no primeiro dia do experimento e realizada a necropsia desses animais no $44^{\circ} \mathrm{dia}$. O total de cordeiros amostrados foi 64 , mas apenas 62 foram necropsiados. As amostras fecais foram examinadas pela técnica de sedimentação espontânea em água. Os conteúdos do abomaso, intestino delgado e intestino grosso dos cordeiros necropsiados foram examinados para a recuperação dos helmintos. Os exames parasitológicos evidenciaram ovos dos seguintes grupos de helmintos: Strongyloidea, Strongyloides sp., Trichuris sp., e Moniezia sp. Também foram encontrados oocistos de Eimeria spp., cistos de Entamoeba ovis e de Giardia duodenalis. Os helmintos identificados a partir do exame dos conteúdos foram: Haemonchus contortus, Cooperia pectinata, Cooperia punctata, Trichostrongylus colubriformis, Moniezia expansa, Oesophagostomum sp. , Skrjabinema ovis e Trichuris sp.

Palavras-chave: Ovinocultura, Haemonchus contortus, Trichostrongylus spp., Giardia duodenalis, ovinos traçadores.

\footnotetext{
*Corresponding author: Maria de Fátima de Souza

Departamento de Microbiologia e Parasitologia - (DMP), Centro de

Biociências - (CB), Universidade Federal do Rio Grande do Norte - UFRN,

Av. Senador Salgado Filho, 3000, Lagoa Nova, Campus Central,

CEP 59072-970, Natal, RN, Brazil;

e-mail:mfsouza@cb.ufrn.br
} 
In Northeastern Brazil, the sheep production has been practiced using local breeds like Morada Nova and Santa Inês. In this region, it's a basic and generalized activity, having a great socio-economic importance because it has been responsible for about $40 \%$ of all animal protein consumed by country population (ALVES, 2005).

In State of Rio Grande do Norte sheep production has been increased, due to breeding herd. Also has been given more attention to animal sanity and production units management, in search of food alternatives to the herd (IDEMA, 2002).

Despite of social and economic importance of sheep production to region and to this State, in particular, some basic challenges must be faced aiming to improve this activity. It includes the systematic searching of knowledges about issues related to epidemiology of parasitic diseases that affect livestock (CHARLES, 1989; SILVA et al., 1998, 2003). Since gastrointestinal parasite infections are implicated as a cause of significant losses in the production of small ruminants (PINHEIRO et al., 2002; VIEIRA, 2005). Considering that, the objective of this study was evaluate gastrointestinal parasitism by helminths and protozoa in sheeps (O. aries) Santa Inês breed, in municipality of Lajes.

This study occurred from April 2005 to August 2007, in which two male lambs Santa Inês breed were sampled in the first day and necropsied in the $44^{\text {th }}$ day of experiment. A total of 64 lambs were sampled, but only 62 were necropsied. The animals were reared extensively, feeding on native vegetation and they were from four to eight months old at the beginning of experiment.

The feces were collected directly from the rectum using silicone collector. The samples were placed in universal collector

Table 1. Parasites identified in 64 fecal samples of lambs Santa Inês collected between April 2005 and August 2007, in municipality of Lajes, State of Rio Grande do Norte.

\begin{tabular}{lcc}
\hline \multicolumn{1}{c}{ Parasite } & $\begin{array}{c}\text { Number of positive } \\
\text { samples }\end{array}$ & $\begin{array}{c}\text { Relative frequency } \\
\text { (\%) }\end{array}$ \\
\hline Eimeria spp. & 36 & 56.25 \\
Strongyloidea & 19 & 29.69 \\
Giardia duodenalis & 12 & 18.75 \\
Entamoeba ovis & 11 & 17.19 \\
Moniezia sp. & 7 & 10.94 \\
Trichuris sp. & 4 & 6.25 \\
Strongyloides sp. & 1 & 1.56 \\
\hline
\end{tabular}

and transported to laboratory in collers, contending ice cubes. Examination of samples was done using the technique of spontaneous sedimentation in water (LUTZ, 1919).

The content of abomasum, small intestine and large intestine of necropsied lambs was removed and fixed at $60{ }^{\circ} \mathrm{C}$. The helminths were separated, counted and identified after clarification in lactophenol (ANDERSON; VERSTER, 1971; EYSKER; KOOYMAN, 1993).

A total de 49 fecal samples had one or more species of parasites, corresponding to $76.56 \%$ of the samples. The most frequent parasitic was Eimeria spp., present in 36 samples $(56.25 \%)$, followed by Strongyloidea, found in 19 samples (29.69\%), and Giardia duodenalis, the third most frequent parasitic, occurred in 12 samples (18.75\%), as shown in Table 1.

The technique used did not allow the identification of Eimeria species. But considering the frequency of that parasitism observed in this present study, we suggest that this parasite should be an important factor for the sheep production in the region. Once that economic losses due to eimeriosis are related to growth rates reduction and animal weight gain, even as susceptibility to another diseases (FITZGERALD, 1980; VIEIRA, 2005).

The giardiosis could be related to self-limiting diarrhea acute staff and also may adverse impact in development and animals of economic interest weight gain (ALOISIO et al., 2006; OLSON et al.,1995).

A total de 15,233 specimens of nematodes were recovered, including adult and immature forms. The number of nematode per animal ranged from 1 to 5,588. Fourteen animals were nematodes free.

The specie $H$. contortus was the most abundant, representing $82.57 \%$ of total nematodes. This specie also was the most prevalent, reaching $82.26 \%$ of animals (Table 2). The pathogenesis importancy of this specie is related to hematofagism (FOX, 1997). The second most abundant specie was T. colubriformis, representing $15.09 \%$ of helminths total and was found in $20.97 \%$ of animals. Other helminth species occurred in smaller proportions (Table 2).

Based on these results, we conclued that lambs had a variety of parasites, including those of renowned veterinary importance such as Eimeria spp., G. duodenalis e H. contortus. Thereby, indicating that the parasites of the gastrointestinal tract constitute a factor to be considered in regard to sheep production in this region of the country.

Table 2. Number of gastrointestinal nematodes recovered of lambs Santa Inês necropsied between April 2005 and August 2007, in municipality of Lajes, State of Rio Grande do Norte.

\begin{tabular}{lcccc}
\hline \multicolumn{1}{c}{ Parasite } & Number of nematodes & Relative frequency (\%) & Infected animals & Relative frequency (\%) \\
\hline Haemonchus contortus & 12,580 & 82.57 & 51 & 82.25 \\
Trichuris sp.** & 85 & 0.56 & 17 & 27.42 \\
Trichostrongylus colubriformis & 2,298 & 15.09 & 13 & 20.97 \\
Cooperia punctata & 35 & 0.23 & 7 & 11.29 \\
Trichostrongylus sp.* & 25 & 0.16 & 7 & 11.29 \\
Oesophagostomum sp.* & 42 & 0.27 & 5 & 8.06 \\
Cooperia pectinata & 161 & 1.06 & 4 & 6.45 \\
Cooperia sp.** & 6 & 0.04 & 4 & 6.45 \\
Skrjabinema ovis & 1 & 0.006 & 1 & 1.61 \\
\hline
\end{tabular}

*Immature forms.**Parasitism by females only. 


\section{Acknowledgements}

FAPERN-CNPq, by financial support. To technician Edson Santana, by his support during field collections. Dr. Vicente Mesquita, by your permission to perform this work on his property and provide the animals used in this study.

\section{References}

Aloisio F, Filippini G, Antenucci P, Lepri E, Pezzotte G, Cacciò SM et al. Severe weight loss in lambs infected with Giardia duodenalis assemblage B. Vet Parasitol 2006; 142(1-2): 154-158. PMid:16891057. http://dx.doi. org/10.1016/j.vetpar.2006.06.023

Alves JU. A tecnologia na convivência com a seca [online]. 2005. Available from: http://www.capritec.com.br/art33.htm.

Anderson PJS, Verster A. Studies on Dictyocaulus filaria. I. Modifications of laboratory procedures. Onderstepoort J Vet Res 1971; 38(3): 181-184. PMid:4277675.

Charles TP. Seasonal prevalence of gastrointestinal nematodes of goats in Pernambuco State, Brazil. Vet Parasitol 1989; 30(4): 335-343. http://dx.doi.org/10.1016/0304-4017(89)90103-9

Eysker M, Kooyman FN. Notes on necropsy and herbage processing techniques for gastrointestinal nematodes of ruminants. Vet Parasitol 1993; 46(1-4): 205-213. http://dx.doi.org/10.1016/03044017(93)90059-V
Fitzgerald PR. The economic impact of coccidiosis in domestic animals. Adv Vet Sci Comp Med 1980; 24: 121-143. PMid:7006338.

Fox MT. Pathophysiology of infection with gastrointestinal nematodes in domestic ruminants: recent developments. Vet Parasitol 1997; 72(3-4): 285-297. http://dx.doi.org/10.1016/S0304-4017(97)00102-7

Instituto de defesa do Meio Ambiente - IDEMA. Perfil do RN [online]. 2002 [cited 2012 Jan 13]. Available from: http://www.idema. rn.gov.br/governo/secretarias/idema/perfilrn/Aspectos-fisicos.pdf.

Lutz A. O Schistosomum mansoni e a Schistosomatose segundo observações feitas no Brazil. Mem I Oswaldo Cruz 1919; 11(1): 121-155.

Olson ME, Mcallister TA, Deselliers L, Morck DW, Cheng KJ, Buret AG et al. Effects of giardiasis on production in a domestic ruminant (lamb) model. Am J Vet Res 1995; 56(11):1470-1474. PMid:8585658.

Pinheiro RR, Alves FSF, Andrioli A. Importância do diagnóstico precoce de doenças em pequenos ruminantes. Sobral: EMBRAPA 2002. 28p. (Embrapa Caprinos, Documentos, 43).

Silva WW, Bevilaqua CML, Costa AL. Natural evolution of gastrointestinal nematodes in goats (Capra hircus) in the semi-arid ecosystem of the Paraíba backwoods, northeastern Brazil. Vet Parasitol 1998; 80(1): 47-52. http://dx.doi.org/10.1016/S0304-4017(98)00188-5

Silva, WW, Bevilaqua, CML, Rodrigues, MLA. Variação sazonal de nematóides gastrintestinais em caprinos traçadores no semi-árido paraibano-Brasil. Rev Bras Parasitol Vet 2003; 12(2): 71-75.

Vieira LS. Endoparasitoses gastrintestinais em caprinos e ovinos. Sobral: Embrapa Caprinos, 2005. 